\title{
A Strategic Evaluation on Competency of Karnataka Destinations through Destination Management Organizations
}

\author{
Bindi Varghese \\ Christ University, Bangalore, India \\ Email: bindi.varghese@christuniversity.in
}

Received 15 January 2016; accepted 19 February 2016; published 22 February 2016

Copyright (C) 2016 by author and Scientific Research Publishing Inc.

This work is licensed under the Creative Commons Attribution International License (CC BY). http://creativecommons.org/licenses/by/4.0/

c) (i) Open Access

\begin{abstract}
The urban and territorial changes caused by tourism are well introspected areas in contemporary scientific literature. This article adopts an integrative approach with a framework connecting scientific traditions of destination management and competitiveness with a case study of Karnataka's destinations. Tourism is a strategic economic activity in Karnataka, but the uniqueness of the governing bodies accentuates integrated planning pioneering with several distinguishing features. The collective investigation of the development of tourism in the state and the recent narration of territorial planning directs towards conclusions regarding the role of Destination Management Organizations in tourism with urban and contemporary development, which has resulted in the creation of a competency model, and the role methodical planning. This paper accentuates the role of DMOs, responding to the need for a destination management. For this purpose the various functionalities, activities and roles of DMOs are evaluated though literature reviews.
\end{abstract}

\section{Keywords}

Tourism, Destination Management, Integrated Planning, Destination Management Organizations (DMOs), Destination Management, Destination Marketing, Competitive Advantage, Urban Planning

\section{Introduction}

Tourism activities come along with multiple benefits, but if tourism is not properly managed it could result in deterioration of the destination leading to a series of disastrous events ranging from rise in unemployment to environmental issues and finally result in irrecoverable and permanent damage caused by the destination in question. So a country interested in developing its destination so as to tap the advantages of tourism ought to care- 
fully plan and analyze several aspects in order to steer away from the negative aspects that arise due to tourism activities and tread towards benefiting from tourism in a positive manner.

In the light of increasing global tourism destinations' competiveness, the limitations of the traditional approaches need to be overcome by new approaches such as the systems approach for tourism destination planning and management (debates Carlsen (1999) [1]). This need can be put into perspective by effective management of a destination.

One of the many successful methods of managing a destination is through Destination Management Organizations (DMOs) which is a body that plays a myriad of roles of which its main function revolves around marketing the tourist destination; apart from this dominant function the DMO also manages destinations' tourism related activities. So in short a DMO is an organization which caters every single aspect of a destination.

The developing and underdeveloped countries lay a lot of emphasis on Vaugeois (2014) [2]. Tourism is chosen for its ability to bring needed foreign exchange earnings, income and employment; tourism has become a popular addition to economic development policies in many African, Asian, South and Central American countries. Hence, this paper seeks to highlight the need for developing and underdeveloped countries to emphasize on the management aspect of tourist destinations through the introduction of the Destination Management Organizations (DMOs). The paper showcases the various destinations that do benefit from DMOs and further relates this to the need of adopting a more holistic approach towards the developing and underdeveloped destinations to progress from sole focus laid on marketing and move towards destination management also.

Thus, in a globalized economy, a DMO has to sustain itself on being "experienced-centric" which calls for the DMO to raise awareness amongst stakeholders that within their network ties are independent and need to have an organizational form. For prompt response from both business to business and business to customer, needs are to be catered, as only then there would be value creation, which a DMO should cater to corporate value and systems (as cited in D'Angella \& Go, 2009, p. 430, 431) [3]. The following literature reviews help understand the concept and cover intricate details of the DMO.

\section{Features, Roles and Activities of a DMO}

Firstly to define DMO, according to the World Tourism Organization (2004) DMO is defined as "organizations responsible for the management and/or marketing of destinations and generally falling into one of the following categories: firstly National Tourism Authorities or Organizations, responsible for management and marketing of tourism at a national level; secondly regional, provincial or state DMOs, responsible for the management and/or marketing of tourism in a geographic region defined for that purpose, sometimes but not always an administrative or local government region such as a county, state or province; and lastly local DMOs, responsible for the management and/or marketing of tourism based on a smaller geographic area or city/town". "Also organizations that fulfilled the role of the above roles, such as City and regional tourist organization or City, Regional \& Provincial Convention Bureau, Sub regional or smaller area DMOs and Convention Bureaux.” fall under the realm of DMOs.

Therefore, this paper raises the question as to the extent of destination management practices followed by these NTOs, RTOs and so on.

The main function of the DMO is examined by various authors such as, Presenza, Sheehan and Ritchie (2005) [4] who gives various views of DMOs as a Destination Marketing Organization and Destination Management Organization. It tries to propose a model that describes the possible activities of DMOs as belonging to an External Destination Marketing (EDM) function or an Internal Destination Development (IDD) function.

A DMO can also be an association of stakeholders formed together with the backing of public authority, as Varghese (2012) [5] explains, DMO is a non-governmental technical body that is voluntary in nature and is usually supported by the Host Government. DMO is a body to initiate a standardized procedure to market a destination by attracting right quantum of tourist, to synergize activities in tourist destinations.

These DMOs are built on the foundation of a solid interest (towards collaboration and corporation) shown on behalf of the stakeholders of the destination, to cite an example of a DMO built on these lines is the Visitor and Convention Bureaus (VCBs) of United States of America, as described by Palmer and Bejou (1995) [6], "motivation coming from within a Chamber of Commerce has often been combined with a desire by other public and private sector agencies to create such a body. A common result has been the development of Visitor and Convention Bureaus (VCBs)” similarly “Tourism Development Action Programs (TDAPs), VCBs generally only 
exist in areas where there is popular support for their introduction among potential collaborators” (p. 623). A DMO seeks to build on a destination brand image unanimously with the stakeholders so the impact and reach of the brand would be larger and more effective.

As Zhang and Murphy (2009) [7] states, the "successful marketing of a destination requires an effective and healthy management mechanism” (p. 279), so the primary function of the DMO is marketing (Dore \& Crouch, 2002) [8].

Presenza, Sheehan and Ritchie (2005) [4] suggest the various activities of a DMO to "be organized into two significant functions external destination marketing and internal destination development” each of these broad functions can be further viewed as an amalgam of specific activities, such as the activities undertaken by the external destination marketing function are "direct sales, direct mail, sales blitzes, trade shows, advertising, familiarization tours, publication and brochures, web marketing, events and festivals and lastly corporative programs” where as the internal destination development function encompasses activities like managing the quality of visitor experience through ensuring that the following are taken care of: "crisis management, human resource development, finance and venture capital and resource stewardship”. Alongside this handle the coordination of stakeholders, information centers and research.

Other than the marketing function as Morgan (2012) [9] explains, “...the DMOs are expected to be destination stewards so as to play the vital role of leading, guiding, and coordinating destination stakeholders”. Thus the DMO builds a tourism destination depending on its carrying capacity, interests of the stakeholders and what kind of benefits the destination want to derive from tourism, in short the "...DMOs determine what kind of a tourism environment they want” (p. 8). Other authors also support the view of DMOs role in the tourism industry being fragmented seeking for coordination and collaboration between the various players in destination marketing (Wang \& Fesenmaier, 2007) [10], so DMOs can facilitate this along with the support of the stakeholders, as the DMO plays the "role of co-ordination and guidance" (Buhalis, 2000) [11].

The role of stakeholders is essential in a destination as, acknowledged by Ruhanen (2012) [12] that academics and non-governmental organizations have stressed the importance of including the stakeholders perspective in planning process, however this has been ignored in practice, so the ill effects of unplanned tourism development hits the resident community, his paper analyzed the approach of strategic visioning as a means to address the stakeholders and achieve the sustainable tourism objectives by adopting a participatory model so as to engage the community with the various stakeholders and government bodies.

Destination Management Organization indeed considers the most important player of the industry that is the tourist, as the "need to select those tourists necessary to achieve maximum profitability/value" (as cited in Fyall et al., 2003, p. 646) [13], this aspect is to be noted by DMOs.

Beeton and Benfield (2002) [14] "suggest that demarketing is appropriate where balance between visitor numbers, revenue and sustainability (economic and environmental) is required. In the management of scarce resources, such as limited capacity and infrastructure, selective de-marketing to market segments that are of less benefit to the destination may be justified” (as cited in Connell, 2005, p. 773) [15]. The DMO fulfills these functions.

Vajcnerova and Ryglova (2010) [16] stresses on the need of a legislatively adjusted system wherein there is an organizational structure is used to manage a tourism destination, the key activity being the maintenance of the quality in tourism services in the tourist destination, thus destination management is used so as to bring about increased destination competitiveness and at the same time to focuses on the sustainability aspect also. The DMO can be implemented to achieve this legislative system, and directly contribute to destination management. The author's also state that destination products are inseparable from the quality of service, therefore the more experienced a tourist the more heightened will be their demand of service quality, thus calls for a need of system of quality. Destination management is essential in bringing about collaboration amidst the various service providers and it helps in managing demand of the tourist destination.

Županović (2010) [17] proposes a strategic model for Montenegro, where during the study period there was a global economic slowdown, the paper seeks to postulate a six stepped model so as improve the potential tourist inflow effectively. It stresses on the concept of cluster making, and forming a destination management organization for each cluster. This can go to show how effective DMOs can be during financial crises as well as with cluster formation a deeper attention can be paid to the details and help solve the problems that may arise. Larger countries can divide their country on the bases of states or clusters to effectively implement the principles of DMOs. 
Other than the above mentioned roles and activities the DMOs also cater to the responsibility of "market research, international market planning and advertising, and organization of events, including travel exhibitions and fairs, is” dealt by NTO/NTAs (World Tourism Organization, 2004). Meriläinen and Lemmetyinen (2011) [18] emphasis on the prominence gained by destination management over the recent decade and its importance is emphasized by its ability to enhance destination competitiveness, thus not only is the destination on the road to development but also treading on the path of better competitiveness.

"In other instances, the DMO serves as a hub firm, or a facilitator, providing a map for destination tourism development. It can also function as a 'controller', permitting firms to carry out certain activities, such as hosting congresses, leisure events and exhibitions. In general, the main purpose of the DMO is to improve the development and management of tourism processes by enhancing coordination and collaboration between the stakeholders concerned at all levels” (Dwyer \& Kim, 2003) (as cited in D’Angella and Go, 2009, p. 431) [19].

\section{Need for DMOs to Undertake Destination Management Practices}

Through several studies it can be derived that the following counties have DMOs. According to a survey undertaken by World Tourism Organization (2004) where 550 DMOs spanning over 29 countries were approached, these DMO consisted of "National Tourism Organizations (NTOs) and Authorities (NTAs), Regional, provincial and state tourism organizations, City tourism organizations, other DMOs such as resort management organizations". This in brief showcases the various forms of DMO across the globe. The question raised here is the management practices followed by these countries.

Bornhorst, Ritchie and Sheehan (2010) [20], conducted an in-depth literature review of 24 articles revolving around DMOs and through their reviews we can draw that majority of the papers on DMOs revolve around marketing and other marketing and promotion, and where as the other stakeholder relation, policy, strategy/holistic perspective and information research alone and no attempt is yet made to enquire into the role played by DMOs in destination management practices.

On the contrary few papers do attempt on studying DMOs role in destination management, such as the study by Saftic, Rafajac, Trost (2010) [21] discussing on the successful destination management strategies, which "depends on the overall level of services quality, which represents the function of DMO and facilitates tourism firms to understand the rising significance of strategic management, of Istrian tourist destinations”. However, concerns are also on the role of DMO in managerial aspect, as, "to make decisions in accordance with a strategy, and to coordinate at the same time current activities and the development component of the destination" (Morgan, 2012) [22]. Questions the DMOs contribution towards social responsibility, stewardship and sustainability agenda by throwing the spotlight on the European destination and marketing organizations, and mainly enquires into those intricate aspects of whether they engage in it.

Benefits derived from DMOs are numerous they play an important role in integrating all the stakeholders as they too play an important role in a destination, DMOs therefore with the help of the stakeholders the DMO can contribute towards building a destinations image, and brand thereby create product and services that attract the right quantum of tourists so that the destination doesn't get hampered, also DMOs come to the aid of destinations in times of disasters and crisis besides this is that platform where prospective tourists can enquire about the destination and serve as a means to come in contact with the travel providers. So the DMO plays several roles and though the most prominent aspect of a DMO is marketing the overall destination management aspect should be considered especially with regards to the developing and underdeveloped countries, as they seem to turn a blind eye towards the need to adopt destination management practices, and are focusing solely on tapping the monetary returns derived from tourism (Varghese, 2014) [23].

Take the example of India, a developing country that offers world-class attractions that can be made competent by attaining high visitor appreciation and systematic marketing effort by the service vendors. Nevertheless in the process, the difficulty lies in leveraging a rationale foundation to initiate collective marketing on behalf of the suppliers. The need also foresee the role of various stakeholders in promoting tourism thereby uplifting the Indian economy in a more methodical process. This can be achieved through the effective implementation of DMOs, where the government can play a lead role in prompting DMO to form a government-industry affiliation to strengthen the Indian tourism brand overseas also to pay more attention to the management of destinations.

For getting an exceptional growth, India needs to lay a wider role in developing an integrated tourism system to share a globally competitive edge. Thereby, destinations need to confer additional attention on management, 
conservation and to channelize innovative patterns for effective citizenship and high economic benefits. Hence the thrust could be leveraged by promulgating effective tourism system thereby, enabling a wider sphere for a better proximity to global success.

\section{Destination Marketing to Destination Management Transfiguration}

There is a need for a paradigm shift from marketing to management, though most Destination Management Organizations (DMOs) flourish with destination marketing as a proactive function many countries especially developing and underdeveloped countries do not take into account the management side of the matter into much consideration.

This view is supported by Gretzel (2008) [24] who says that despite the rising global importance of destination marketing organizations there exists few studies on its management. Pike (2013) [25] argues the contentious issue regarding, the tendency of authors in referring Destination Marketing Organizations (DMO) as Destination Management Organizations. Both these terms differ on several grounds mainly that, destination marketing organizations, rarely practice destination management. Moreover, analysis is required on the grounds of conducting more academic research regarding the complexities of destination management.

This shift is still being debated by scholars, the general understanding is that management being the broader subject, and marketing just an aspect that arises in it. So marketing invariably falls to be a part of management and not vice versa, moreover there will be a steady rise in the need for proper planning, control and management in the future on comparison to marketing. Therefore, marketing will not be the only aspect that destinations require but emphasis will also be laid on management of the destination so in the long run the change may occur in the terminology of Destination Marketing Organizations to Destination Management Organizations.

\section{Problems Faced by Developing and under Developed Countries DMOs}

A DMO will be posed with several challenges as Pike (2008) [26] stated that as the focal point of the tourism system is that the tourist destination constantly faces challenges that the destination marketer has no control over, thus the DMO is constantly bombarded with challenges. As Gretzel, Fesenmaier, Formica and O’Leary (2006) [27], specified the basic challenges for DMOs: being the adaptation to technological changes, management of expectations, change from marketing the destination to the management of destination, face new levels of competition, to recognize creative partnership and lastly to find new ways to achieve success.

Other than this the developing and underdeveloped countries may face issues with the non-compliance of the stakeholders, "one of the challenges is the question of the willingness of travel agencies to undertake these efforts” Zhang and Murphy (2009) [28] as they may not be keen on collaboration. A solution to this is that the government should influence the "tourism industry by their power to legislate and to impose regulations on the industry” (Marzano \& Scott, 2009) [29]. Also another reason for their non-compliance could be the lack of awareness regarding DMOs the benefits the stakeholders can derive this could be compensated for by keen interest take by the public sector in promoting DMOs popularity.

Also, Pike (2012) [30] studies on the challenge that the DMOs face with regard to, "achieving differentiation against the myriad of competing places offering similar features, by positioning their destination into consumers' decision sets” (p. 100), with DMOs interest in branding since the 1990's, it is seen that brand positioning “can be a source of competitive advantage for organizations" (p. 101), but with the challenge posed as mentioned the road towards it is rough.

\section{Future Implications of DMO}

Destination Management Organizations (DMOs) play a crucial role in a destination, not only in destination marketing but also in bringing about sustainable development; balancing the interests of all the stakeholders; and sustenance of the competitiveness within the destination so as to properly manage the destination. Magas (2010) [31] foresees that, DMO as a strategic leader and a destination developer, will "simplify partnership and co-operation in accordance with the common vision of the destination”. Moreover a DMO standardizes the procedures for destination development by setting up benchmarks for destination branding, deterring business entities which do not foster the standards set by DMOs, and developing a yardstick to ensure that the set objectives are adhered, to propose corrective actions during the non compliance by the participants and lastly to incorporate 
the implications of DMOs in strengthening the academic curriculum.

Tourism destination marketing is heavily reliant on promotion and this will be the case even in the future as there is a growing need for bringing about a holistic means of achieving destination competiveness to better the destination in terms of sustainability. One take of doing this is that the stakeholders along with the destination have to take a stance on gaining a more strategic perspective in planning, development and marketing by the support of DMOs.

\section{References}

[1] Carlsen, J. (1999) A Systems Approach to Island Tourism Destination Management. System Research and Behavioral Science, 16, 321-327. http://dx.doi.org/10.1002/(SICI)1099-1743(199907/08)16:4<321::AID-SRES255>3.0.CO;2-5

[2] Vaugeois, N. (2014) Tourism in Developing Countries: Refining a Useful Tool for Economic Development. http://fama2.us.es:8080/turismo/turismonet1/economia\%20del\%20turismo/economia\%20del\%20turismo/tourism\%20a nd\%20developing\%20countries.pdf

[3] D’Angella, F. and Go, F.M. (2009) Tale of Two Cities Collaborative Tourism Marketing: Towards a Theory of Destination Stakeholder Assessment. Tourism Management, 30, 429-440. http://dx.doi.org/10.1016/j.tourman.2008.07.012

[4] Presenza, A., Sheehan, L. and Ritchie, J.R.B. (2005) Towards a Model of the Roles and Activities of Destination Management Organizations.

http://www.academia.edu/1009194/Towards_a_model_of_the_roles_and_activities_of_destination_management_orga nizations

[5] Varghese, B. (2012) Intervention of Destination Management Organization's in Tourist Destinations for Branding, Image Building and Competitiveness-A Conducive Model for Karnataka. International Journal of Investment and Management, 2, 50-56. http://dx.doi.org/10.11648/j.jim.20130203.13

[6] Palmer, A. and Bejou, D. (1995) Tourism Destination Marketing Alliances. Annals of Tourism Research, 22, 616-629. http://dx.doi.org/10.1016/0160-7383(95)00010-4

[7] Zhang, Y. and Murphy, P. (2009) Supply-Chain Considerations in Marketing Underdeveloped Regional Destinations: A Case Study of Chinese Tourism to the Goldfields Region of Victoria. Tourism Management, 30, 278-287. http://dx.doi.org/10.1016/j.tourman.2008.07.004

[8] Dore, L. and Crouch, G.I. (2003) Promoting Destinations: An Exploratory Study of Publicity Programmes Used by National Tourism Organizations. Journal of Vacation Marketing, 9, 137-149. http://dx.doi.org/10.1177/135676670300900203

[9] Morgan, N. (2012) Time for Mindful Destination Management and Marketing. Journal of Destination Marketing \& Management, 1, 8-9. http://dx.doi.org/10.1016/j.jdmm.2012.07.003

[10] Wang, W. and Fesenmaier, D.R. (2007) Collaborative Destination Marketing: A Case Study of Elkhart County, Indiana. Tourism Management, 28, 863-875. http://dx.doi.org/10.1016/j.tourman.2006.02.007

[11] Buhalis, D. (2000) Marketing the Competitive Destination of the Future. Tourism Management, 21, 97-116. http://dx.doi.org/10.1016/S0261-5177(99)00095-3

[12] Ruhanen, L. (2012) Strategic Visioning: Integrating Sustainable Development Principles in Tourism Destination Planning. Acta Turistica, 24, 149-176.

[13] Fyall, A., Callod, C. and Edwards, B. (2003) Relationship Marketing the Challenge for Destinations. Annals of Tourism Research, 30, 644-659. http://dx.doi.org/10.1016/S0160-7383(03)00046-X

[14] Beeton, S. and Benfield, R.W. (2002) Demand Control: The Case for Demarketing as a Visitor and Environmental Management Tool. Journal of Sustainable Tourism, 10, 479-513. http://dx.doi.org/10.1080/09669580208667184

[15] Connell, J. (2005) Toddlers, Tourism and Tobermory: Destination Marketing Issues and Television-Induced Tourism. Tourism Management, 26, 763-776. http://dx.doi.org/10.1016/j.tourman.2004.04.010

[16] Vajcnerova, I. and Ryglova, K. (2010) The Application of Quality Management Principles into the Management of the Destination. The Business Review, Cambridge, 16, 306-311.

[17] Županović, I. (2010) New Postulates in Strategic Management of Integrated Tourist Destination Product in Montenegro. Tourism \& Hospitality Management.

[18] Meriläinen, K. and Lemmetyinen, A. (2011) Destination Network Management: A Conceptual Analysis. Tourism Review, 66, 25-31. http://dx.doi.org/10.1108/16605371111175302

[19] D’Angella, F. and Go, F.M. (2009) Tale of Two Cities' Collaborative Tourism Marketing: Towards a Theory of Destination Stakeholder Assessment. Tourism Management, 30, 429-440. http://dx.doi.org/10.1016/j.tourman.2008.07.012

[20] Bornhorst, T., Ritchie, J.R.B. and Sheehan, L. (2010) Determinants of Tourism Success for DMOs \& Destinations: An 
Empirical Examination of Stakeholders’ Perspectives. Tourism Management, 31, 572-589. http://dx.doi.org/10.1016/j.tourman.2009.06.008

[21] Saftić, D., Rafajac, O. and Trošt, K. (2010) DMO Model as a Step Forward in Quality of the Management of Istrian Tourist Destination. Tourism \& Hospitality Management.

[22] Morgan, N. (2012) Time for “Mindful” Destination Management and Marketing. Journal of Destination Marketing \& Management, 1, 8-9. http://dx.doi.org/10.1016/j.jdmm.2012.07.003

[23] Varghese, B. (2014) A Literature Review on Destination Management Organization. ZENITH International Journal of Multidisciplinary Research, 4, 82-88.

[24] Gretzel, U. (2008) Managing Destination Marketing Organizations: The Task, Role, and Responsibilities of Convention and Visitor Bureau Executive. Annals of Tourism Research, 35, 1083-1093. http://dx.doi.org/10.1016/j.annals.2008.06.008

[25] Pike, S. (2013) Destination Marketing and Management: Theories and Applications. Tourism Management, 34, 247253. http://dx.doi.org/10.1016/j.tourman.2012.07.005

[26] Pike, S. (2008) Managing Destination Marketing Organizations: The Task, Role, and Responsibilities of Convention and Visitor Bureau Executive. Tourism Management, 29, 1246. http://dx.doi.org/10.1016/j.tourman.2008.03.008

[27] Gretzel, G., Fesenmaier, D.R., Formica, S. and O’Leary, J.T. (2006) Searching for the Future: Challenges Faced by Destination Marketing Organizations. Journal of Travel Research, 45, 116-126. http://dx.doi.org/10.1177/0047287506291598

[28] Zhang, Y. and Murphy, P. (2009) Supply-Chain Considerations in Marketing Underdeveloped Regional Destinations: A Case Study of Chinese Tourism to the Goldfields Region of Victoria. Tourism Management, 30, 278-287. http://dx.doi.org/10.1016/j.tourman.2008.07.004

[29] Baggio, R., Scott, N. and Cooper, C. (2009) Improving Tourism Destination Governance: A Complexity Science Approach. Tourism Review, 65, 51-60.

[30] Pike, P. (2012) Destination Positioning Opportunities Using Personal Values: Elicited through the Repertory Test with Laddering Analysis. Tourism Management, 33, 100-107. http://dx.doi.org/10.1016/j.tourman.2011.02.008

[31] Magas, D. (2010) Why the Destination Management Organization? Tourism \& Hospitality Management, 2010, 10411047. 